\title{
Students' Common Mistakes in Technical Texts When Using Computer Technologies
}

\author{
Tatiana Klepikova* \\ Institute of Energy, Irkutsk National Research Technical University,664074, 83 Lermontov St., Irkutsk, Russia, \\ klepiktv@gmail.com
}

\begin{abstract}
The paper considers the possibilities of using computer technologies by students in the translation of scientific and technical texts on power and electrical engineering. The main task of the study was to identify advantages and disadvantages of machine or computer-aided translation through their comparison and to define the possibility of their use in the translation of texts on power and electrical engineering. Among other types, students and post-graduates prefer machine translation. The comparison of two the most popular machine translation systems on the basis of Google Translate statistics and PROMT rules texts on power and electrical engineering showed that the Google Translate gives the better quality translation of special terms of this subject-matter. The majority of participants of the students' international competition on written translation of the CIGRE Russian National Committee use Google Translate and PROMT. Translation mistakes are the result of insufficient language training and indistinct understanding of the described technical process. When translating written texts students shall apply post-editing and use the electronic dictionary Multitran. The development of hybrid machine translation systems on the basis of rules and statistics will allow shifting to a qualitatively new level of technical translation. The quality of students' translations significantly increases if they participate in international and domestic competitions and get a profound knowledge of specialized subjects.
\end{abstract}

\section{Introduction}

The use of computer technologies in technical translation becomes ever more relevant since the development of the Internet expands the access to the latest information innovative technologies and developments in foreign languages. Without knowing the original language, the use of online English educational literature and study manuals is only possible through online translators.

The perception of modern machine translation programs as universal automated translation tools able to replace human translators is based on wrong assumptions. Due to innovative methods, the modern development of computer technologies makes it possible to find numerous data. Based on this, some users believe that it automatically leads to high-quality transformation in translation from a source to a corresponding target language. The majority of today's students of technical universities have basic knowledge of foreign languages, mainly, of English, German, and French. Most students have more advanced knowledge in computer technologies, including computer translation technologies. The objective requirement is to define automated resources of the Internet, which ensures fast and high-quality translation of research literature and technical documentation. However, the knowledge of a language and specialized terminology in this field do not guarantee adequate and exact translation with the corresponding terminology since there is a need to possess both the corresponding technical knowledge and skills of written translation.

\section{Results and Discussion}

At present, the Internet offers more than 100 online translation services that differ in their functionality and quality; however, these translation systems can also be distinguished by their functional application. The use of computer technologies in the translation of scientific and technical texts requires the understanding of machine and automated translation systems since there are some differences in their functional application. Hence, the objective of this study is to determine the main advantages and disadvantages of the most popular online translators and possibilities of their application in written translation of scientific and technical literature in English.

Machine translation is the process of translating texts (written, and ideally oral) from one natural language to another by means of special computer programs, which also serves the name for the research focusing on the development of similar systems [1]. The development of machine translation as a scientific and applied study began in the late $1940 \mathrm{~s}$ of the $20^{\text {th }}$ century. Today, the

* Corresponding author: klepiktv@gmail.com 
most popular programs and Internet services of machine translation used in Russia are PROMT, Google Translate, Yandex Translate. The algorithms of machine translation are designed following two fundamentally different approaches. Such machine translation systems as PROMT, SYSTRAN, Linguatec are rule-based machine translation (RBMT) systems. Yandex Translate and Google Translate statistical-based machine translation (SBMT) systems [2].

Let us consider features of two algorithms of machine translation. The Rule-Based Machine Translation (RBMT) includes dictionaries, grammar structures of initial and target languages. In this case the initial sentence is broken down to separate parts of speech where standard structures are selected; words and phrases are translated according to dictionaries stored in computer memory. Then, the translated parts of speech are united by rules of a target language. Thus, the combination of structures of both languages is the cornerstone of the rule-based machine translation (RBMT).

Statistical-based machine translation (SBMT) is developed by comparing large volumes of language pairs, i.e. sentences in source and target languages. The quality of translation depends on the quantity of language pairs - the bigger their quantity, the better the translation. In other words, statistical-based machine translation (SBMT) is based on statistical analysis, i.e. the analysis of statistics of linguistic, syntactic structures, etc. [3].

The main feature of machine translation is that it is based on the generation of translations following the grammatical analysis of a source text.

Machine-aided or machine-assisted translation (MAT) is the translation of texts by a person with the use of specialized computer programs aimed to improve the quality of translation [4]. Machine-aided translation distinguishes three types of text editing in a source language: pre-editing, inter-editing and post-editing. Preediting allows a translator to transform a text in order to remove ambiguous statements and to simplify the syntax of sentences. The conversion of a source text at lexicalsemantic and syntactic levels provides for higher-quality translation of the text. Machine-aided translation with inter-editing implies the involvement of a translator to make the necessary modifications. Inter-editing may include the removal of uncertainty within sentences containing multivalent words and choice of the most suitable grammatical structure. Post-editing assumes the translator is working with machine translation to adjust the translated text in compliance with norms of a target language. The best translation result is possible provided all three forms of translation are used, i.e. when preediting, inter-editing and post-editing are combined [5].

Often, machine-aided translation uses dictionaries called the Translation Memory (TM). The translation memory includes the creation of databases of translated texts in two languages. One entry in such database corresponds to a "translation unit" representing one sentence (less often - a part of a compound sentence, or a paragraph). Previous translations are stored in the database for their possible use and fast search of similarities. If a sentence of a source text exactly matches a sentence stored in the database, it can be automatically added to the translation. If a new sentence slightly differs from the sentence stored in the database, then it can be added to the translation, however the translator shall make the necessary changes. Such computer programs assisted by the translation memory are called computer-aided/assisted translation (CAT) [6]. At present the most popular translation memory systems are as follows: OmegaT, SDLX, TRADOS, Deja Vu, Star Transit, Trans Suite 2000, WordFast, WordFisher, ACROSS. Besides the above listed, the machine-aided translation uses such effective tools as text corpora proposed in 1984 by Makoto Nagao, a Japanese developer of computer technologies. The Japanese researcher suggested to reject the word-by-word and grammatical analysis of phrases, and offered to translate a new text by analogy, i.e. to create a translation of a new text from parallel fragments (phrases, sentences, paragraphs) from already translated texts thus identifying lexical differences and replacing the corresponding words [7]. Corpora includes texts in one or several languages consisting of a set of units. Each unit contains the original block and one or several translations. The corpora make compressed description of the use of words and expressions collected according to certain subject-domains, supplied with summaries and a specialized search engine [8].

Table 1 shows some advantages and disadvantages of machine and machine-aided translation.

The differences between machine and machine-aided translations confirm the fact that machine-aided translation systems are used by professional translators. They ensure better translation. Machine translation can help, for instance, in emergency situations when a person does not know a language, but needs the translation urgently despite non-perfect translation quality.

Machine translation of scientific and technical texts uses dictionaries, which include semantic units of different levels: words, phrases, sentences. In modern times, the complexity of machine translation is the fact that the source text defines grammatical forms and word order in the translated text on the basis of syntactic links between words. Besides, dictionaries used in machine translation mostly represent the dictionaries of words but not phrases.

At the given stage of scientific development the translation errors through computer translation technologies are inevitable. Experience shows that nonprofessional translators, scientists, students, and engineers use machine translation systems. Let us consider an example of translation of a text segment in electrical engineering into Russian using online Google Translate and PROMT and compare them with professional translation.

While the multiple failures in the valve windings were significantly affected by the quality of oil i.e. the presence of the semiconducting Copper Sulfide resulting from the application of the corrosive oil and the failures in the OLTC could partly be attributed to the transient phenomena associated with the converter operation, the increasing failure rate in the 
Table 1. Comparison of machine and machine-aided translation.

\begin{tabular}{|c|c|c|}
\hline Translation system & Advamtages & Disadvantages \\
\hline Machine translation & $\begin{array}{c}\text { Free access to translation services; } \\
\text { Possibility of translation from different languages; } \\
\text { Fast translation speed; } \\
\text { Translation of heavy texts with a huge speed; } \\
\text { Translation of Web pages in real time; } \\
\text { Translation based on linguistic formal rules of a } \\
\text { language. }\end{array}$ & $\begin{array}{c}\text { Syntactic bonds of a compound sentence parts are not } \\
\text { considered; } \\
\text { Dictionaries do not match the rules of grammar, } \\
\text { stylistics and vocabulary; } \\
\text { Lack of dictionaries or incomplete compliance in } \\
\text { technical disciplines; } \\
\text { Separate technical terms if not included in the } \\
\text { dictionary are not translated. }\end{array}$ \\
\hline $\begin{array}{l}\text { Machine-aided } \\
\text { translation }\end{array}$ & $\begin{array}{c}\text { Possibility of translation from different languages; } \\
\text { Maximum use of earlier translations; } \\
\text { Storage of translation results and editing within the } \\
\text { database; } \\
\text { Possibility of storage of the initial document } \\
\text { formatting in } 100 \% \text { translation; } \\
\text { Opportunity of improving the corpora quality; } \\
\text { Expansion of translation memory and corpora. }\end{array}$ & $\begin{array}{c}\text { The majority of machine translation systems have no } \\
\text { free access; } \\
\text { Translation speed is defined by qualification of a } \\
\text { translator and volume of discrepancies within a } \\
\text { translation database; } \\
\text { Need to create a translation memory and corpora on a } \\
\text { particular subject-domain; } \\
\text { Requires editing; } \\
\text { Electronic dictionaries often give several translation } \\
\text { options of an initial word to a target language and } \\
\text { hence, a translator has to posess specialized knowledge } \\
\text { of a translated subject; } \\
\text { Rules of grammar and syntax are not considered. }\end{array}$ \\
\hline
\end{tabular}

connection could be attributed to the increased design complexity and increasing voltage levels.

Online Google Translate: " $B$ то время как многочисленные отказы в обмотках клапанов существенно влияли на качество масла, то есть присутствие полупроводникового медного сульфида в результате применения коррозионного масла $u$ сбоев в ОLTC частично можно было отнести к явлениям переходного прочесса, связанным $c$ преобразователем работа, увеличение частоты отказов в соединении может быть связано $c$ повышенной сложностью конструкции и увеличением уровней напряжения".

Online PROMT Translator: " $B$ то время как многократные неудачи в обмотках клапана были значительно затронуты качеством нефти т.е. присутствием полупроводникового медного сульфида, следующего из применения коррозийной нефти, и неудачи в OLTC могли частично быть приписаны переходным прочессам, связанным $с$ эксплуатацией конвертера, увеличивающаяся интенсивность отказов в связи могла быть приписана увеличенной сложности дизайна $и$ увеличиваюшимся уровням напряжения".

Translator: "Так как на многократные отказы в вентильных обмотках значительно повлияло качество масла, т.е. присутствие полупроводникового сульфида меди как следствие применения коррозионного масла, и аварии в РПН (устройство регулирования напряжения трансформаторов) можно частично объяснить переходным процессом, связанным с операцией преобразования, то рост частоть отказов в схемах соединений можно связать с повышенной сложностью конструкиии и ростом уровней напряжения".
Quite often in the translation of multivalent words machine translators select one notion, sometimes inappropriate to a particular context: the valve windings - обмотки клапанов, while a professional translator offers: the valve windings as вентильные обмотки.

In a subordinate clause the Google Translate translated a passive voice of were affected with an active voice "отказы влияли на качество масла", while a professional translator translated it as " $\mathrm{а} \mathrm{отказы}$ повлияло качество масла". The machine translation tortured the physical meaning of a phenomenon since low-quality oil may influence multiple failures and not vice versa. Transformer oils are used to fill power and measuring transformers and are intended for insulation of current-carrying parts and nodes of a power transformer [9].

Online PROMT Translator correctly transfers syntax translation rules of a verb in a subordinate clause, but the majority of specialized technical terms are translated from a general translated dictionary: multiple failures, valve windings, oil, failures, converter operation, failure rate, design complexity.

The quality of translation is a key parameter in translation theory. It shall be admitted that there is not ideal technology capable to ensure high-quality translation of a large technical text from one language to another thus maintaining the narrative style of a professional translator.

The improvement of students' translation skills is an important component of their professional qualification since the present time imposes strict requirements to the knowledge of foreign languages for the development of scientific and technical progress. In this regard, since 2012 the youth workshop of the Russian National Committee of the Conseil International des Grands Réseaux Électriques (CIGRE RNA) has been holding the 
annual competition of translators of scientific and technical literature in electrical and power engineering among students of the leading Russian technical schools. The competition is intended for full-time bachelor, specialist (engineers), master, and post-graduate students in electrical and power engineering [10].

The analysis of students' works presented for the 2017 competition on the translation of scientific and technical literature in electrical and power engineering of the youth workshop of the Russian National Committee (RNA) showed that the majority of students used Google Translators and PROMT. Among translation errors the following were the most frequent:

- logical;

- syntactic;

- lexical.

Stylistic errors were absent since the texts were purely scientific and technical, and the author's assessment was not required.

The analysis of translations revealed some striking examples of mismatches of source and target languages.

1. A second parameter (response signal) is usually a voltage taken across the measurement impedance connected to a second transformer terminal with reference to the tank (it may also be a current measured at the input terminal or at some other grounded terminal).

Второй параметр (сигнал отклика) обычно представляет собой напряжение, принимаемое через измеритель импеданса, подключенное ко второй клемме трансформатора относительно его бака (это так же может быть ток, измеренный относительно входной клеммы или на какой-либо другой заземленной клемме).

Второй параметр (выходной сигнал) обычно представляет собой напряжение, принимаемое через комплексное сопротивление измерения, подключенное ко второй клемме трансформатора относительно его бака (это так же может быть ток, измеренный относительно входной клеммы или на какой-либо другой заземленной клемме).

Сигнал отклика is a logical error - wrong translation of a denotative meaning of the text. A syntactical error included the literal translation. Измеритель импеданса is a lexical error - calquing of the original, there is no word импенданс in Russian.

2. In back-to-back application the inrush current seen by a single bank will be increased when other capacitor banks are already connected to the same bus.

При применении подключения друг к другу импульс, при включении наблюдаемый, влияющий на единичную батарею, будет увеличен, когда другие конденсаторные батареи уже подключеньк ктой же шине.

При использовании подключения возврата энергии в сеть пусковой ток, наблюдаемьий при включении одной батареи, будет увеличен, когда другие конденсаторные батареи уже подключень к той же шине.

Друг $\kappa$ другу is a syntactical error - literal translation. The logical error is that the program makes literal translation: влияющиий на единичную батарею, correct translation of the term is наблюдаемыци при включении одной батареи.

3)Voltage breakdowns at capacitive current interruption are divided into re-ignitions and restrikes.

Просадки напряжения при емкостном прерывании делятся на повторные зажигания $u$ пробои.

Электрические пробои напряжения при прерывании емкостного тока делятся на повторные разряды и пробои.

Просадки - wrong translation of a denotative text since the term is relevant for construction industry, for example, просадка грунта, electrical engineering uses the term электрические пробои, the term зажигание is applied in automotive industry while разряды are used in electrical engineering; a syntactic mistake - violation of a functional feature of the original text.

The program produced the ready term-phrase without taking into account the area to which the text belongs.

4) Tunnel laid GIL and cables offer in general a higher current rating than direct buried because of better ventilation.

Туннель заложен линий с элегазовой изоляциией $u$ кабель, как правило, имеют более высокий номинальный ток, чем прямой забой, благодаря лучшей вентиляции.

Проложенные в туннеле линии с элегазовой изоляцией и кабели, как правило, имеют более высокий номинальный ток, чем прямо проложенные в грунте, благодаря лучшей вентиляции.

Туннель заложен линий is a syntactic mistake since there is a violation of a functional feature of the original text. Google translates laid as a predicate, which in fact is the attributive, while the predicate is offer.

Прямой забой is a lexical mistake and calquing of words, ... is a logical mistake.

Thus, the review of translations showed that machine translation may generally be considered as literal translation. As practice shows, translation of scientific and technical articles using machine translation requires further post-editing of texts. Logical, syntactic and lexical mistakes appear as a result of insufficient language training of students and incomplete understanding of described technical processes. There are some exercises to prevent the translation mistakes mentioned above. Experience shows that the main translation difficulty is not finding an equivalent of a word or a phrase but reorganizing a sentence or a text fragment in a suitable syntactic manner of a target language. This task may also be a cornerstone for students with sound language background. One of approaches to develop skills in translation of written and oral texts from Russian into English are exercises on simple paraphrasing in the native language. In practice, the ability to quickly paraphrase an initial statement before its translation makes its lexical and grammatical structure very similar to the structure of a required phrase in a target language. Such exercises prevent literal translation, teach students to focus on meaning thus avoiding ambiguities and inaccuracies [11]. 


\section{Conclusions}

At present, machine translation of technical texts to make sure the process of exchange of scientific and technical information is sufficient still does not correspond to specified objectives. Therefore, there is a need to continue theoretical study, to expand the experimental basis in this field and to develop modern computer technologies and its software at a higher level. Further improvement of existing and creation of new automated specialized dictionaries will make it possible to increase their quality. The development of hybrid machine translation systems (HMT) through the integration of advantages of two machine translation systems based on RBMT and SMT will dramatically improve the translation quality, develop innovative translation methods and increase the content of bilingual terminological dictionaries [12].

Two main technologies: Statistical machine translation (Statistical machine translation - SMT) and Machine translation on the basis of rules (Rule-Based Machine Translation - RBMT).

To reduce translation errors to a minimum in the translation of scientific and technical articles it is necessary to maintain the accuracy of terminology, abbreviations and acronyms used in a target language with regard to syntactic constructions, to consider rules of using numbers, symbols, units of measure, to pay attention to requirements to a final translation. Therefore, translations made via online translators need post-editing, which may be done using one of the most complete and the most popular automatic online dictionaries that ensures high-quality translation of technical terminology of the RuNet - Multitran.

The involvement of students in national and international competitions on the translation of scientific and technical literature, additional training on advanced translation skills fosters students' practical knowledge and skills in scientific and technical translation; helps to acquire professional terminology and notions; ensures skills of stylistic design of translation and preparation of presentations in a foreign language, and allows mastering innovative computer translation technologies.

\section{References}

1. Machine

translation,

URL: https://ru.wikipedia.org/wiki/Mashinnyy perevod (date of access: 05.11.2017)

2. A. A. Arestova, Bulletin of Volgograd State University. Series 9. Researches of young scientists, 13 (2015).

3. A. D. Andreyeva, I. L. Menshikov, A. A. Mokrushin, Young scientist, 12 (2013)

4. Machine translation, URL: https://ru.wikipedia.org/wiki/Avtomatizirovannyy_p erevod (date of access: 09.11.2017)

5. O. I. Babina, Bulletin of Chelyabinsk State University. 24 (2011)
6. Lecture 4. Automated and machine translation, URL: https://refdb.ru/look/1179285.html (date of access: 09.11.2017)

7. Corpus-based mashine translation, URL http://lab314.brsu.by/kmplite/kmp2/Translation/MT/MT-Corpus/MTCorpus.htm (date of access : 09.02.2018).

8. V. N. Shevchuk, Electronic resources of a translator: Reference materials for translators, (Librayt, Moscow, 2010)

9. B. N. Sergeyenkov, V. M. Kiselyov, N. A. Akimova, Electrical machines: Transformers, (Higher school, Moscow 1989)

10. Competition of translators of scientific and technical literature in English, URL: http://www.cigre.ru/rnk/youth/ (date of access: 29.11.2017)

11. E. Yu. Pishkova, Measure of translation errors and ways of its prevention, Humanities and social sciences. Rostov-on-Don, 2 (2015)

12. Hybrid machine translation, URL: https://ru.wikipedia.org/wiki/Gibridnyy_mashinnyy _perevod (date of access: 15.02.2018)

\footnotetext{
*Corresponding author: klepiktv@gmail.com
} 